\title{
Determination of Concentration of Some Heavy Metals in Tissues of Cattle Slaughtered From Southern Agricultural Zone of Nasarawa State, Nigeria
}

Sabuwa A.M ${ }^{1} \&$ Nafarnda W.D ${ }^{1}$

${ }^{1}$ Department of Veterinary Public Health and Preventive Medicine, Faculty of Veterinary Medicine, University of Abuja, Abuja, Nigeria

\author{
Article History \\ Received: 24.08.2020 \\ Accepted: 08.09.2020 \\ Published: 30.09 .2020
}

Journal homepage:

https://www.easpublisher.com/easjvms

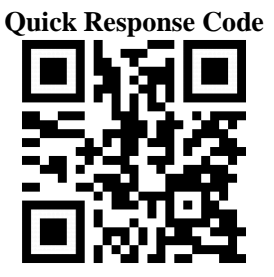

\begin{abstract}
The study was undertaken to determine the presence and concentration of some heavy metals in selected tissues of cattle slaughtered from southern agricultural zone of Nasarawa state using Atomic Absorption Spectrophotometer (AAS). Fifty samples comprising 10 each of liver, kidney, skin, intestine and muscle were collected and analyzed for the presence of $\mathrm{Ni}, \mathrm{Cr}, \mathrm{Pb}, \mathrm{Cu}$ and $\mathrm{Cd}$. Male and female cattle of two age categories (Young and Older) were sampled for the study. The mean concentration of $\mathrm{Ni}, \mathrm{Pb}, \mathrm{Cu}$ and $\mathrm{Cd}$ in all the sampled tissues were generally low and within the permissible limit. High levels of $\mathrm{Cr}$ was detected in all samples with mean concentration of $3.9926 \mathrm{mg} / \mathrm{kg}, 2.4440$ $\mathrm{mg} / \mathrm{kg}, 2.9909 \mathrm{mg} / \mathrm{kg}, 2.1688 \mathrm{mg} / \mathrm{kg}$ and $4.0100 \mathrm{mg} / \mathrm{kg}$ in intestine, kidney, liver, muscle and skin respectively. There exist significant difference $(\mathrm{P}<0.05)$ in the mean concentration of $\mathrm{Ni}$ and $\mathrm{Cu}$ between young and older cattle. Higher levels of $\mathrm{Cr}, \mathrm{Pb}$ and $\mathrm{Cd}$ was detected in the tissues of female animal than male. The result from this study indicates that cattle slaughtered from the study area are free from $\mathrm{Cd}, \mathrm{Cu}, \mathrm{Ni}$ and $\mathrm{Pb}$ residues, but contained high levels of $\mathrm{Cr}$. Public and private sector should establish cattle ranches so as to reduce the possibility of grazing cattle in heavy metal contaminated feed and pasture.

Keywords: Abattoir, Agricultural zone, heavy metals, tissues, AAS, cattle, Nasarawa state.
\end{abstract}

Copyright (C) 2020 The Author(s): This is an open-access article distributed under the terms of the Creative Commons Attribution 4.0 International License (CC BY-NC 4.0) which permits unrestricted use, distribution, and reproduction in any medium for non-commercial use provided the original author and source are credited.

\section{INTRODUCTION}

Nigeria is considered the most populous country in Africa (WHO, 2015) and one of the consequences of increased human population is environmental pollution and it is possible to establish relationships between overpopulation, poverty and urban air pollution (Chen B and Kan H, 2008). Heavy metal contamination of food is an issue of global concern that ultimately results in toxicity and diseases in humans and animals through consumption of contaminated soils and food (Michael et al., 2018). These metals are natural components of the environment but high rate of industrialization has been responsible for their wider diffusion and dispersal in the environment (Rajaganapathy et al., 2011). Contaminated food is one of the main sources of exposure to heavy metals and an increased dietary heavy metal intake may contribute to the development of various disorders (Michael et al., 2018). Heavy metals toxicosis in animals occurs when livestock ingest contaminated forage and water or inhalation of contaminated air from their surroundings. This ultimately bio-accumulate in the tissues and organs such as liver, kidney, which are consumed by humans as a source of animal protein (Okareh OT, 2015). Anthropogenic activities such as mining, use of inorganic agricultural products, unselective dumping of waste on land and water contribute to the existence of toxic metals in the ecosystem (Jayasekara et al., 1992). Other anthropogenic sources of heavy metal contamination include agricultural activities, such as pesticide and herbicide application, contaminated irrigation water, municipal waste used for fertilization of crops (Alloway \& Jackson, 1991), mineral fertilizer containing traces of heavy metals and direct waste disposal on farmland (Merian et al., 2004). Somasundaram et al., (2005), in their study conducted in India established that giving animals feeds from areas with elevated content of trace elements results in their bioaccumulation in edible tissues, eggs and milk.

The risk associated with the exposure to heavy metals present in food products had aroused widespread concern in human health (Reilly, 1991). Improvements in the food production and processing technology had increased the chances of contamination of food with various environmental pollutants, especially heavy metals. Ingestion of these contaminants by animals causes deposition of residues in meat (Sabir et al., 
2003). Higher level of trace metals has been recorded in beef and mutton. Presence of substantiates levels of toxic metals including lead and cadmium in meat products has been reported by González Weller et al., 2006.

Some heavy metals are consider as essential metals, they exert biochemical and physiological functions in plants and animals. They are important constituents of several key enzymes and play important roles in various oxidation-reduction reactions (WHO, 1996).

In biological systems, heavy metals have been reported to affect cellular organelles and components such as cell membrane, mitochondrial, lysosome, endoplasmic reticulum, nuclei, and some enzymes involved in metabolism, detoxification and damage repair (Wang S and Shi X, 2011). The fast rate of urbanization and industrialization in the study area informed the necessity of this study. The aim of the study is to determine the concentrations of heavy metals as well as the effect of age and sex in slaughtered cattle from southern agricultural zone of Nasarawa state.

\section{Materials ANd Methods Study area}

The study was conducted in southern agricultural zone of Nasarawa state Nigeria. The zone is among the three agro-ecological region of the state and consist of five local government areas. The area falls within the Guinea Savanna agroecological zone and is found between latitudes $7^{\circ} 52 \mathrm{~N}$ and $8^{\circ} 56 \mathrm{~N}$ and longitudes $7^{\circ} 25 \mathrm{E}$ and $9^{\circ} 37 \mathrm{E}$ respectively. The state has a mean monthly temperatures between $20^{\circ} \mathrm{C}$ and $34^{\circ} \mathrm{C}$, with annual rainfall ranging between $1100 \mathrm{~mm}$ to 2000 mm (Lyam A, 2000).

\section{Sample type}

The sample consist of liver, kidney, intestine, muscle and skin

Sample collection
Overall total of 75 tissue samples were collected from slaughtered cattle during the period of study which lasted between April to August 2018. These comprise of 15 samples each of liver, kidney, intestine, muscle and skin. The characteristics (age, sex and breed) of all the sample cattle were recognized and recorded accordingly. About $10 \mathrm{~g}$ of sampled tissues were collected, labeled and stored separately in clean polythene bags and transported in an ice pack containing ice block where they were refrigerated at temperature of $2^{\circ} \mathrm{c}$ to $8^{\circ} \mathrm{c}$.

\section{Sample Digestion}

Conventional Wet Acid Method of Digestion as described by Miranda et al., (2005) was used. $5 \mathrm{ml}$ of freshly prepared mixture of concentrated HNO3 (nitric acid) and $\mathrm{H} 2 \mathrm{O} 2$ (hydrogen peroxide) in a $4: 2 \mathrm{v} / \mathrm{v}$ ratio was poured into a Pyrex flask containing $2 \mathrm{ml}$ of the blood samples and left for 15 minutes. Watch glass was used to cover the flask prior to digestion. A total of $3 \mathrm{ml}$ of $\mathrm{HNO} 3$ and few drops of $\mathrm{H} 2 \mathrm{O} 2$ were used to treat the digest followed by subsequent heating at $80^{\circ} \mathrm{C}$ on a hot plate to obtain a clear digested solution. The excess acid mixture was evaporated to a semi-dry mass and thereafter cooled and diluted with $0.2 \mathrm{ml}$ nitric acid. A $100 \mathrm{ml}$ volumetric flask was used to transfer the mixture and diluted with distilled water to obtain a 60 $\mathrm{ml}$ volume. The samples were stored in a refrigerator at $4^{\circ} \mathrm{C}$ awaiting Atomic Absorption Spectrophotometer (AAS) analysis.

\section{Analysis of samples}

Atomic Absorption Spectrophotometer (Manufactured by Shimadzu, Model AA 6800, Japan) was used to evaluate the concentrations of heavy metals in the digested samples at the laboratory of the National Research Institute for Chemical Technology, Zaria, Nigeria. A calibration of the AAS was done with standard solutions after which they were aspirated into the AAS equipment for analysis. Concentration of $\mathrm{Pb}$, $\mathrm{Cd}, \mathrm{Ni}, \mathrm{Cu}$ and $\mathrm{Cr}$ were evaluated using descriptive statistic while Student t-test was used to analyzed the effect of age and sex on the concentration of the metals using Statistical Package for Social Sciences (SPSS, 2010) version 20.0 for Windows.

\section{RESUlts AND DisCUSSION}

Table 1: Distribution of cattle according to age and sex

\begin{tabular}{lll}
\hline Parameters & Number examined & Percentage (\%) \\
\hline Age & & \\
Adult & 38 & 76.00 \\
Old & 12 & 24.00 \\
Total & $\mathbf{5 0}$ & $\mathbf{1 0 0 . 0 0}$ \\
Sex & & \\
Male & 5 & 10.00 \\
Female & 45 & 90.00 \\
Total & $\mathbf{5 0}$ & $\mathbf{1 0 0 . 0 0}$ \\
\hline
\end{tabular}


Table 1 shows the distribution of sampled cattle according to sex and age. Out of the 50 cattle sampled for the study, $76 \%$ (38) were young cattle of age $<5$ years. While $24 \%$ (12) were older cattle of age $>5$ years. Male cattle were $10 \%$ (5) while $90 \%$ (45) of the sampled cattle were female. This shows that most of the cattle slaughtered in the study area are female, the male are usually reserved for festival and breeding as shown by Sabuwa et al., (2019).

Table 2: Mean concentration of heavy metals in cattle as affected by type of organ

\begin{tabular}{lllllllll}
\hline Parameters & Intestine & Kidney & Liver & Muscle & Skin & SEM & SD & LOS \\
\hline Nickel & 0.1090 & 0.0044 & 0.0153 & 0.0430 & -0.0815 & 0.0297 & 0.2102 & $\mathrm{~ns}$ \\
Copper & 0.0041 & 0.0029 & 0.0036 & 0.0037 & 0.0009 & 0.0009 & 0.0061 & $\mathrm{~ns}$ \\
Chromium & 3.9926 & 2.4440 & 2.9909 & 2.1688 & 4.0100 & 0.9718 & 6.8719 & $\mathrm{~ns}$ \\
Lead & 0.0355 & 0.0710 & 0.0691 & 0.0534 & 0.0546 & 0.0083 & 0.0587 & $\mathrm{~ns}$ \\
Cadmium & 0.0007 & 0.0007 & 0.0010 & 0.0005 & -0.0001 & 0.0003 & 0.0020 & $\mathrm{~ns}$ \\
\hline
\end{tabular}

$\mathrm{SEM}=$ standard error of mean; $\mathrm{LOS}=$ level of significance; $\mathrm{ns}=$ not significantly different $(\mathrm{P}>0.05)$.

The mean concentrations $(\mathrm{mg} / \mathrm{kg})$ of $\mathrm{Ni}, \mathrm{Cu}$, $\mathrm{Cr}, \mathrm{Pb}$ and $\mathrm{Cd}$ of tissues sampled from southern agricultural zone of Nasarawa state are presented in table 2 above. $\mathrm{Cr}$ is the most detected metal while $\mathrm{Cd}$ is the least detected metal from all tissue samples. Highest mean concentration $(\mathrm{mg} / \mathrm{kg})$ of $\mathrm{Cr}$ is detected in skin than liver, kidney, intestine and muscle. This findings is not in line with the studies of Bala et al., (2014) and that of Akan et at. (2010) who shows that liver bioaccumulate heavy metals more than any organ of the body. A very low concentration of chromium in muscle $(0.011 \mathrm{mg} / \mathrm{kg})$, liver $(0.022 \mathrm{mg} / \mathrm{kg})$ and kidney $(0.025$ $\mathrm{mg} / \mathrm{kg}$ ) was reported by Fathy et al., (2011), these values were over 200 times lower than detected in this study. The concentrations $(\mathrm{mg} / \mathrm{kg})$ of $\mathrm{Cr}$ from all the tissue samples far exceed the maximum permissible limit recommended by codex alimentarious. The high concentrations $(\mathrm{mg} / \mathrm{kg})$ of $\mathrm{Cr}$ in all the sampled tissues may indicates that the cattle have recently been exposed to either $\mathrm{Cr}$ contaminated feed or $\mathrm{Cr}$ contaminated environment as a result of anthropogenic activities. This is in line with the findings of Tchounwou et al., (2012) who shows that Chromium enters into various environmental matrices (air, water and soil) from a wide variety of natural and anthropogenic sources with the largest release coming from industrial establishments. Environmental exposure to $\mathrm{Cr}$ containing compounds is known to cause multiorgan toxicity such as renal damage, allergy and cancer of the respiratory tract (Goyer RA, 2001). $\mathrm{Cr}$ is a toxic industrial pollutant that is classified as human carcinogen by several regulatory and non-regulatory agencies (UEPA, 1992).

The intestine have the highest concentration of $\mathrm{Ni}$ when compared with other tissues, with a mean concentration that is 20 times higher than the mean concentration of Kidney $(0.0044 \mathrm{mg} / \mathrm{kg})$. Skin recorded the lowest mean concentration of $\mathrm{Ni}$. The mean concentration of $\mathrm{Ni}$ in liver $(0.0153 \mathrm{mg} / \mathrm{kg})$ is greater than the concentration of kidney $(0.0044 \mathrm{mg} / \mathrm{kg})$. Iwegbue, C. M. A. (2008) in his study conducted in southern Nigeria recorded high levels of $\mathrm{Ni}$ in Kidneys $(0.20 \mathrm{mg} / \mathrm{kg})$ and Liver $(0.12 \mathrm{mg} / \mathrm{kg})$ than concentration recorded in this study conducted in North central Nigeria. Although, Ni plays a vital role in the body by regulating prolactine and stabilization of RNA and DNA structures, excessive amount of $\mathrm{Ni}$ produces severe allergic reaction, bronchial asthma, dermatitis and myocardial infection as shown by C.R.K. Murtic and P. Viswanathan (1989).

The liver recorded highest mean concentration $(\mathrm{mg} / \mathrm{kg})$ of $\mathrm{Cd}$ when compared with the mean concentration $(\mathrm{mg} / \mathrm{kg})$ of other tissues. This high relative mean concentration of $\mathrm{Cd}$ in the liver indicates that the liver bio-accumulates Cadmium more than any organ in the body. This findings does not agree with the study of Iwegbue AMC (2008) who shows that Kidney accumulates cadmium more than all organs of the body. Generally, the mean concentration $(\mathrm{mg} / \mathrm{kg}$ ) of $\mathrm{Cd}$ from cattle tissues recorded from the study area are very low and insignificant. This shows that the environment where these cattle are raised is free from $\mathrm{Cd}$ contamination. This is in agreement with the study of Miranda et al., (2009) who reported that cattle and other ruminants are indicators of environmental contamination with heavy metals. Cadmium is toxic to almost every system in the animal body, it is almost absent in the human body at birth but accumulates with age (Mukesh K. R. et al., 2008). Cd compounds are classified as human carcinogens by the International Agency for Research on Cancer (IARC, 1993).

The concentration of $\mathrm{Pb}$ is highest in Kidney $(0.0710 \mathrm{mg} / \mathrm{kg})$, followed by the liver $(0.0691 \mathrm{mg} / \mathrm{kg})$, least concentration was detected in intestine $(0.0355$ $\mathrm{mg} / \mathrm{kg}$ ). This is in line with the study of Flora, SJS (2006) who showed that the greatest percentage of lead in the body concentrate more in the kidney and the liver. All the sampled tissues recorded concentration that is lower than the recommended daily intake of 0.1 $\mathrm{mg} / \mathrm{kg}$ (FAO, 2011). The level of $\mathrm{Pb}$ in tissues and blood has a significant correlation with the levels and metabolism of essential trace metals (Singh et al., 1994). Ahmed et al., (2007) in India studied the in vivo interaction of $\mathrm{Pb}$ with some essential trace elements in the blood of underage children, and their results showed 
significant association between elevated blood $\mathrm{Pb}$ levels and the risk of anemia. This establish that elevated tissues $\mathrm{Pb}$ levels will results in a corresponding decrease in the concentration of some essential metals in animal and human body. Bala et al., in their study conducted in Sokoto, north western Nigeria reported an elevated mean concentration of $\mathrm{Pb}$ in liver (1.523 $\mathrm{mg} / \mathrm{kg})$ and kidney $(0.8442 \mathrm{mg} / \mathrm{kg})$ of cattle, values that are extremely higher than the values obtained from this study conducted in north central Nigeria. M. Zahuru et al., (2011) in their study conducted in Bangladesh to determine the levels of $\mathrm{Pb}$ in slaughtered cows reported a high mean $\mathrm{Pb}$ concentration $(0.7 \mathrm{mg} / \mathrm{kg})$ in liver that is over 10 times the concentration detected in this study.
Highest $\mathrm{Cu}$ concentration $(\mathrm{mg} / \mathrm{kg})$ is detected in the intestine with least concentration observed in Kidney. This study recorded very low levels of $\mathrm{Cu}$ compared to the studies of Oymak et al., (2017), who reported $15.82 \mathrm{mg} / \mathrm{kg}$ in Kidney, $280.86 \mathrm{mg} / \mathrm{kg}$ in liver and that of Iwegbue, C. M. A, (2008) who reported mean concentration of $1.99 \mathrm{mg} / \mathrm{kg}$ and $3.27 \mathrm{mg} / \mathrm{kg}$ in liver and kidney respectively from southern Nigeria. Although, $\mathrm{Cu}$ is an essential metal that is required for the formation of red blood cells, as well as many oxidation and reduction reactions in humans and animals, elevated levels in the tissues is toxic. The low levels of $\mathrm{Cu}$ detected in the tissues of cattle from this study indicates that the environment were these cattle are raised is deficient of some trace metals.

Table 3: Mean concentration of heavy metals in cattle as affected by sex

\begin{tabular}{llllll}
\hline Parameters & Male & Female & SEM & Standard deviation & LOS \\
\hline Nickel & 0.0271 & 0.0170 & 0.0297 & 0.2102 & $\mathrm{~ns}$ \\
Copper & 0.0031 & 0.0030 & 0.0009 & 0.0061 & $\mathrm{~ns}$ \\
Chromium & 2.6983 & 3.1682 & 0.9718 & 6.8719 & $\mathrm{~ns}$ \\
Lead & 0.0220 & 0.0606 & 0.0083 & 0.0587 & $\mathrm{~ns}$ \\
Cadmium & -0.0005 & 0.0007 & 0.0003 & 0.0020 & $\mathrm{~ns}$ \\
\hline
\end{tabular}

$\mathrm{SEM}=$ standard error of mean; LOS = level of significance; $\mathrm{ns}=$ not significantly different $(\mathrm{P}>0.05)$.

The results for mean concentrations $(\mathrm{mg} / \mathrm{kg})$ of $\mathrm{Ni}, \mathrm{Cu}, \mathrm{Cr}, \mathrm{Pb}$ and $\mathrm{Cd}$ as affected by sex is presented in table 3 above. $\mathrm{Cr}$ is the most detected metal while $\mathrm{Cd}$ is the least detected metals from both male and female cattle. The concentrations $(\mathrm{mg} / \mathrm{kg})$ of $\mathrm{Ni}$ and $\mathrm{Cu}$ are highest in tissues of male cattle than female. Higher levels of $\mathrm{Cr}, \mathrm{Pb}$ and $\mathrm{Cd}$ is detected in female animal then male. The mean concentration $(0.0606 \mathrm{mg} / \mathrm{kg})$ of
$\mathrm{Pb}$ in female animal is over two times the concentration $(0.0220 \mathrm{mg} / \mathrm{kg})$ in male. This is in line with the study of Sabuwa et al., (2019) who shows that female cattle tends to accumulates high levels of $\mathrm{Pb}$ and $\mathrm{Cd}$ in their tissues than male. No significant difference exist in the concentrations of $\mathrm{Ni}, \mathrm{Cu}, \mathrm{Cr}, \mathrm{Pb}$ and $\mathrm{Cd}$ between male and female cattle.

Table 4: Mean concentration of heavy metals in cattle as affected by age

\begin{tabular}{llllll}
\hline Parameters & Young & Old & SEM & Standard Deviation & LOS \\
\hline $\mathrm{Ni}$ & -0.0363 & 0.1901 & 0.0297 & 0.2102 & $*$ \\
$\mathrm{Cu}$ & 0.0043 & -0.0010 & 0.0009 & 0.0061 & $*$ \\
$\mathrm{Cr}$ & 2.8086 & 4.1114 & 0.9718 & 6.8719 & $\mathrm{~ns}$ \\
$\mathrm{~Pb}$ & 0.0639 & 0.0338 & 0.0083 & 0.0587 & $\mathrm{~ns}$ \\
$\mathrm{Cd}$ & 0.0005 & 0.0008 & 0.0003 & 0.0020 & $\mathrm{~ns}$ \\
\hline
\end{tabular}

$\mathrm{ab}$ means on the row having different superscript differ significantly; SEM = standard error of mean; LOS = level of significance; $\mathrm{ns}=$ not significantly different $(\mathrm{P}>0.05)$

Table4 represent mean concentrations of $\mathrm{Ni}$, $\mathrm{Cu}, \mathrm{Cr}, \mathrm{Pb}$ and $\mathrm{Cd}$ in young and older cattle. Highest mean concentration of $\mathrm{Ni}, \mathrm{Cr}$ and $\mathrm{Cd}$ is detected in the tissues of older cattle than the young age category. Significant $(\mathrm{p}<0.05)$ high concentration $(0.0043$ $\mathrm{mg} / \mathrm{kg}$ ) of $\mathrm{Cu}$ was detected in the tissues of young cattle when compared with the older cattle. There exist significant difference $(\mathrm{P}<0.05)$ in the mean concentration of $\mathrm{Ni}$ in older and younger cattle, with high concentration detected in young age category. No significant difference $(\mathrm{P}>0.05)$ exist in the concentration of $\mathrm{Cr}, \mathrm{Pb}$ and $\mathrm{Cd}$ between young and older cattle.

\section{CONCLUSION}

The study revealed cattle slaughtered from southern agricultural zone of Nasarawa state accumulate some levels of heavy metals in their tissues. The concentrations of $\mathrm{Ni}, \mathrm{Cd}, \mathrm{Cu}$ and $\mathrm{Pb}$ are low and within the permissible limits. $\mathrm{Cr}$ was found in high concentration in all tissues and above the permissible limit of FAO. Sex have no significant effect on the concentrations of heavy metals in cattle tissue. Age have significant effect $(p<0.05)$ in the concentrations of some heavy metals in cattle slaughtered from southern agricultural zone of Nasarawa state, north central Nigeria. Although, the concentrations of most of the heavy metals were found to be generally low, it is important for the continuous evaluation of these metals 
from both animals and the environment of the study area so as to reduce their bioaccumulation in cattle and human tissues. Public awareness on the danger of grazing cattle near industrial and auto-mobile factories should be advocated.

\section{REFERENCES}

1. Ahamed, M., Singh, S., Behari, J. R., Kumar, A., \& Siddiqui, M. K. J. (2007). Interaction of lead with some essential trace metals in the blood of anemic children from Lucknow, India. Clinica chimica acta, 377(1-2), 92-97.

2. Akan, J.C., Abdulrahman, F.I., Sodipo, O.A., \& Chiroma, Y.A. (2010). Distribution of Heavy Metals in the Liver, Kidney and Meat of Beef, Mutton, Caprine and Chicken from Kasuwan Shanu Market in Maiduguri Metropolis, Borno State, Nigeria. Res. J. Appl. Sci. Eng. Technol. 2(8):743-748.

3. Alloway, B.J., \& Jackson, A.P. (1991). Behavior of trace metals in sewage sludge-amended soils. Science of the Total Environment. 10.1016/00489697(91)90377-Q.

4. Bala, A., Suleiman, N., Junaidu, A. U., Salihu, M. D., Ifende, V. I., Saulawa, M.A., Magaji, A. A., Faleke O. O., \& Anzaku .S. A. (2014). Detection of Lead $(\mathrm{Pb})$, Cadmium (Cd), Chromium (Cr) Nickel (Ni) and Magnesium Residue in Kidney and Liver of Slaughtered Cattle in Sokoto Central Abattoir, Sokoto State, Nigeria. International Journal of Livestock Research, 4(1): 74-80.

5. Chen, B., \& Kan, H. (2008). Air pollution and population health: a global challenge. Env Health and Prev Med. 13(2), 94-101.

6. FAO. (2011). Joint FAO/WHO food standards program codex committee on contaminants in foods, 5(1): 50-54

7. Flora, S. J., Flora, G., \& Saxena, G. (2006). Environmental occurrence, health effects and management of lead poisoning. In Lead (pp. 158228). Elsevier Science BV.

8. Gonzales-Waller, D., Karlsson L., Caballero, A., Hernandez, F., Gutierrez, A., Gonzalez-Igalesias, T., Marino, M., \& Hardission A., (2006). Lead and cadmium in meat and meat products consumed by the population in Tenerife Islands. Food Additives \& Contaminants. 23(3):757-763.

9. Goyer, R. A. (2001). Toxic effects of metals. In: Klaassen, CD., editor. Cassarett and Doull's Toxicology: The Basic Science of Poisons. New York: McGraw-Hill Publisher; 2001. p. 811-867

10. International Agency for Research on Cancer (IARC). (1993). Monographs - Cadmium. Lyon, France.

11. Iwegbue, A.M.C. (2008). Heavy metal composition of livers and kidneys of cattle from southern Nigeria. Veterinarski Arhi. 78(5), 401-410.
12. Jayasekara, S., Samarajeewa, U., \& Jayakody, A. N. (1992). Trace metals in foods of animal origin in Srilanka. Asian Food Journal, 7(2), 105-107.

13. Khalafalla, F. A., Ali, F. H., Schwagele, F., \& AbdEl-Wahab, M. A. (2011). Heavy metal residues in beef carcasses in Beni-Suef abattoir, Egypt. Veterinaria italiana, 47(3), 351-361.

14. Lyam, A. (2000). Nasarawa State. In: Mamman, A. B., Oyebanji, J. O., \& Peters, S. W (Eds.). Nigeria: A people united, a future assured. Survey of states. 2(2). Federal Ministry of Information. Abuja.

15. Merian, E., Anke, M., Inhat, M., \& Stoeppler, M. (2004). Elements and their compounds in the environment. Wiley $\mathrm{VCH}$, Weinhem, Germany. Pp 79-86.

16. Miranda, M., Benedito, J. L., Blanco-Penedo, I., López-Lamas, C., Merino, A., \& López-Alonso, M. (2009). Metal accumulation in cattle raised in a serpentine-soil area: relationship between metal concentrations in soil, forage and animal tissues. Journal of Trace Elements in Medicine and Biology, 23(3), 231-238.

17. Miranda, M., Lopez-Alonso, M., CASTILlO, C., Hermandez, J., \& Benedito, J.L. (2005). Effects of moderate pollution on toxic and trace metals levels in calves from a polluted area of northern Spain. Environmental Instrumentation. 31, 543-548.

18. Murtic, C.R.K., \& Viswanathan, P. (1989). "Toxic metals in the Indian, environment" Wiley Eastern Ltd., New Delhi.

19. Okareh, O.T. (2015). Determination of Heavy Metals in Selected Tissues and Organs of Slaughtered Cattle from Akinyele Central Abattoir, Ibadan. Journal of Biology, Agriculture and Healthcare. 5(11):124-9.

20. Onakpa, M. M., Njan, A. A., \& Kalu, O. C. (2018). A review of heavy metal contamination of food crops in Nigeria. Annals of global health, 84(3), 488-494.

21. Raikwar, M. K., Kumar, P., Singh, M., \& Singh, A. (2008). Toxic effect of heavy metals in livestock health. Veterinary world, 1(1), 28-30

22. Rajaganapathy V., Xavier, F., Sreekumar, D., \& Mandal, P. K. (2011). Heavy metal contamination in soil, water and fodder and their presence in livestock and products. Journal of Environmental Science and technology, 4(3), 234-249.

23. Reilly, C. (1991). Metal contamination of food. London-New York: Elsevier Applied Science. p 3151.

24. Sabir, M. S., Khan, S. W., \& Hayat, I. (2003). Effect of environmental pollution on quality of meat in district bagh. Azas Kashmir Pakistan. Journal of Nutrition, 2(2), 98-101.

25. Sabuwa, M.A.B., Salihu, M.D., Baba, M.K., \& Bala, A. (2019). Determination of concentration of some heavy metals in the blood of HolsteinFriesian cattle on a farm in Nasarawa State, 
Nigeria. Sokoto Journal of Veterinary Sciences. 17(3), $17-23$.

26. Singh, B., Dhawan, D., Nehru, B., Garg, M. L., Mangal, P. C., Chand, B., \& Trehan, P. N. (1994). Impact of lead pollution on the status of other trace metals in blood and alterations in hepatic functions. Biological trace element research, 40(1), 21-29.

27. Somasundaram, J., Krishnasamy, R., \& Savithri, P. (2005). Biotransfer of heavy metals in Jersey cows. Indian Journal of Animal Science. 75(11): 12571260

28. SPSS (2010). Statistical package for Social Sciences. SPSS Inc., 444 Michigan Avenue, Chicago. IL60611, 2010

29. Tchounwou, P. B., Yedjou, C. G., Patlolla, A. K., \& Sutton, D. J. (2012). Heavy metal toxicity and the environment. In Molecular, clinical and environmental toxicology (pp. 133-164). Springer, Basel.

30. Turkey, K. (2017). Some heavy metal contents of various slaughtered cattle tissues in SivasTurkey. J. Turk. Chem. Soc, 4, 721-728.

31. U.S. EPA. (1992). Environmental Criteria and Assessment Office. Cincinnati, OH: United States Environmental Protection Agency; 1992. Integrated Risk Information System (IRIS).

32. Wang, S., \& Shi, X. (2001). Molecular mechanisms of metal toxicity and carcinogenesis. Mol Cell Biochem. 222:3-9.

33. WHO/FAO/IAEA. World Health Organization. Switzerland: Geneva; 1996. Trace Elements in Human Nutrition and Health.

34. World Health Organization. http://www.who.int/countries/nga/en/; 2015. 